\title{
REČ UREDNIKA
}

\section{FINANSIJSKO IZVEŠTAVANJE BLIŽE ZAHTEVIMA EU ACQUIS}

Propisi su stalno u kaskanju za realnim potrebama. Finansijsko-izveštajni propisi Srbije su inovirani 2013. godine, kada smo dobili odvojene Zakon o računovodstvu i Zakon o reviziji. U međuvremenu je zabeležena samo minorna intervencija $u$ ovim propisima, $\mathrm{u}$ smislu preciziranja obaveza $\mathrm{u}$ vezi sa novim standardima u oblasti sprečavanja i otkrivanja pranja novca i finansiranja terorizma.

Kaskanje naših propisa se meri razdaljinom $u$ odnosu na propise EU. Nije u pitanju da li kaskamo iza, već koliko kaskamo iza. Kuriozitet je da su postojeća dva zakona o finansijskom izveštavanju, donesena 2013, postavljena na osnovama stare regulative EU. Dakle, naše poslednje inoviranje je izvedeno na osnovama EU regulative koja je u tom trenutku bila već zastarela.

\section{KOJE IZMENE DOLAZE?}

Put izmena regulative finansijskog izveštavanja u Srbiji je trasiran zahtevima koji važe za finansijsko izveštavanje $u$ skladu sa EU acquis. Na put promena ukazuju i specijalizovana tela koja monitoruju situaciju u Srbiji, među kojima najviši rang ima Svetska banka sa svojom specijalizovanom institucijom - Centrom za reforme finansijskog izveštavanja. Kardinalne nalaze ova institucija daje kroz svoje ROSC izveštaje, koji se za pojedine države objavljuju na nekih deset godina.

Očekivanja su da će doći do nekoliko značajnih promena. Prvo, menjaće se kriteriji po kojima se određuje veličina pravnih lica. Lestvice su prethodno jednom podignute, sada sledi novo podizanje. Kao što je dosad bilo nekog labavljenja kriterija, moguće je da će ga ponovo biti. Ali lestvice će se svakako podići. Drugo, teret finansijskog izveštavanja mora biti srazmeran kapacitetima izvestioca. Treće, entiteti od javnog interesa su izgleda preširoko definisani i moraju se 
redefinisati. Četvrto, izveštavanje na korporativnom nivou se mora uskladiti prema EU aquis zahtevima. Peto, odbori za reviziju dobijaju obavezu jačeg i transparentnijeg delovanja. Šesto, srednja preduzeća ne bi trebalo da primenjuju pune IFRS. Sedmo, obaveza izveštavanja o konsolidovanim entitetima za male entitete se sigurno redefiniše. Osmo, pravilnici i Kontni plan će se sigurno adekvatno izmeniti. Ovo su samo naznake krupnih promena, a biće ih sigurno još.

Svi su izgledi da će u regulativi revizije biti više promena. Promene se očekuju, najpre u nadgledanju. Ovde su nagoveštene mnogo oštrije oči nadglednika, mnogo gušće sito za neadekvatnosti revizora, mnogo više odvojenosti i nezavisnosti organa nadgledanja od samih praktičara, a kontrola kvaliteta mnogo striktnija. Drugo, uz ove promene visoka je verovatnoća za uvođenje više ispitivanja i nametanja disciplinskih mera prema revizorima. Treće, biće pokretanja gonjenja prekršilaca u finansijskom izveštavanju osposobljavanjem istražitelja i suda za tu funkciju. Četvrto, sve ovo nagoveštava drugačije alociranje nekih funkcija na relaciji Komora ovlašćenih revizora - Odbor za javno nadgledanje - Ministarstvo finansija.

Kompleks gornjih promena je usmeren na jačanje revizije, što znači snažan pritisak na revizore od kojih se zahteva više i koji se moraju adekvatno ustrojiti i pripremiti za složenije zahteve i preciznije izveštavanje.

\section{ZA NOVI UZLET - NOVI NAPOR}

Svi su izgledi da dolaze vrlo ozbiljne promene i zatezanje odgovornosti na svim karikama lanca finansijskog izveštavanja, počev od računovođa i svih onih koji sastavljaju i prezentiraju finansijske izveštaje, preko revizora koji ispituju i verifikuju te izveštaje, do nadgledanja i procesiranja onih koji nisu usaglašeni i uzrokuju distorzije u finansijskim izveštajima.

Ovim se otvara prostor za zaista ozbiljne promene na institucionalnom i individualnom planu. To je novi uzlet ka višem kvalitetu finansijskih informacija i stvaranju jačeg poverenja u njih. Pouzdanije informacije su osnov za donošenje boljih ekonomskih odluka i za bolju poslovnu klimu.

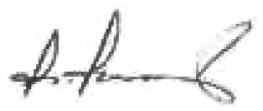

